\title{
SPIRIZOMACARE TERHADAP TINGKAT KECEMASAN PADA PASIEN PRE OPERASI MAYOR
}

\author{
Juwati Prasetyaningsih ${ }^{1}$, Ayu Pratiwi ${ }^{2}$ \\ 1,2 Prodi Ilmu Keperawatan STIKes Yatsi, Tangerang \\ Jl. Aria Santika No. 40A, RT 005/RW011 Margasari, Kec. Karawaci, Kota Tangerang, \\ Banten, Indonesia \\ juwijuwati80@gmail.com
}

\begin{abstract}
Abstrak
Operasi mayor memiliki resiko tinggi karena mengandung resiko-resiko yang bisa mengancam kesehatan dan keselamatan pasien. Kondisi tersebut memberikan dampak psikologis pada pasien pre operasi, seperti timbul rasa ketakutan dan kecemasan. Kecemasan dapat ditangani secara farmakologi maupun nonfarmakologi. Spirizomacare (spiritual zikir aromacare) merupakan salah satu terapi nonfarmakologi dengan cara mengabungkan zikir dengan aromaterapi untuk mengatasi kecemasan. Tujuan penelitian ini yaitu untuk mengetahui pengaruh Spirizomacare terhadap tingkat kecemasan pada klien sebelum melakukan tindakan pre operasi mayor di RSUD Cilegon. Metode Penelitian dengan desain pra ekperimental one group pretest posttest. Populasi pasien yang akan melakukan operasi mayor sebanyak 30 responden. Pengambilan sampel dengan teknik purposive sampling. Instrumen yang digunakan berupa lembar kuesioner dan observasi. Teknik analisa data menggunakan analisa Univariat dan Bivariat dengan uji Paired T Test. Hasil penelitian menunjukkan ada pengaruh spirizomacare terhadap tingkat kecemasan pada klien sebelum melakukan pre operasi mayor, dengan hasil, $p$ value sebesar $0,000<0,05$. Spirizomacare merupakan terapi non farmakologi yang terbukti efektif untuk menurunkan tingkat kecemasan pada pasien pre operasi, khususnya operasi mayor.
\end{abstract}

Kata kunci : Operasi, Kecemasan, Spirizomacare

\begin{abstract}
Major surgery has a high risk because it contains risks that can threaten the health and safety of the patient. These conditions have a psychological impact on preoperative patients, such as fear and anxiety arise. Anxiety can be treated pharmacologically and non-pharmacologically. Spirizomacare (spiritual remembrance aromacare) is a non-pharmacological therapy by combining remembrance with aromatherapy to treat anxiety. The purpose of this study was to determine the effect of Spirizomacare on the level of anxiety in clients before performing major preoperative actions at Cilegon Hospital. Research method with pra experimental design one group pretest posttest. The population is patients who will perform major surgery as many as 30 respondents. Sampling with purposive sampling technique. The instruments used are questionnaires and observation sheets. The data analysis technique used Univariate and Bivariate analysis with Paired T Test. The results showed that there was an effect of spirizomacare on the level of anxiety in clients before performing pre-major surgery, with the result, $p$ value of $0.000<0.05$. Spirizomacare is a non-pharmacological therapy that has been proven to be effective in reducing anxiety levels in preoperative patients, especially major surgery.
\end{abstract}

Keywords : Surgery, Anxiety, Spirizomacare

\section{PENDAHULUAN}

Operasi adalah tindakan yang saat ini telah banyak dilakukan dalam pengobatan beberapa penyakit. World Health Organization (WHO) pada tahun 2013 mencatat bahwa jumlah tindakan operasi mengalami peningkatan yang signifikan. Tahun 2011 di rumah sakit seluruh dunia terdapat 140 juta pasien dengan tindakan operasi, tahun 2012 mengalami peningkatan menjadi 148 juta pasien (Fadli, Toalib, \& Kassaming 2017).

Data Riskesdas (2018) mencatat

Corresponding author:

Juwati Prasetyaningsih

juwijuwati80@gmail.com 
tindakan operasi mayor sebanyak $75 \%$ telah dilakukan dengan spesifikasi semua kasus divisi bedah. Lebih dari $60 \%$ pada kasus digestif, sedangkan presentase lain merata pada kasus divisi bedah lainnya seperti divisi anak, plastik onkologi, vaskuler thorax, urologi dan orthopedi.

Data dari Dinas Kesehatan Provinsi banten di dapatkan hasil jumlah pasien melakukan operasi baik Minor maupun Mayor pada tahun (2020) yakni sebanyak 9.106 kasus, sedangkan data yang ditemukan di RSUD Cilegon pada bulan Desember tahun 2020 terdapat sebanyak 197 kasus pasien yang melakukan operasi bedah mayor di RSUD Cilegon dengan tingkat kecemasan yang berbeda-beda.

Operasi mayor memiliki resiko tinggi karena mengandung resiko-resiko yang bisa mengancam kesehatan dan keselamatan pasien. Kondisi tersebut memberikan dampak psikologis pada pasien pre operasi, seperti timbulnya rasa ketakutan dan kecemasan. Dampak psikologis yang umum diantaranya takut tindakan anastesi, takut rasa nyeri, takut cacat atau anggota tubuh tidak bisa berfungsi normal kembali, dan lain hal sebagainya (Ahsan, Retno, \& Sriati 2017).

Cemas merupakan sebuah kondisi yang menimbulkan ketidaknyamanan pada seseorang. Sedangkan kecemasan merupakan suatu emosi dan pengalaman subjektif dalam diri seseorang (Rizki, Hartoyo, \& Sudiarto2019).

Kecemasan dapat ditangani secara farmakologis maupun nonfarmakologis. Spiriziomacare merupakan salah satu terapi kecemasan nonfarmakologi. Spiriziomacare adalah sebuah terapi kecemasan dengan penggabungan antara zikir dengan aromaterapi. Zikir berfungsi sebagai pendekatan spiritual dengan merubah kecemasan dengan pendekatan dir pendekatan kepada Allah (Handayani 2018).

Zikir digabungkan dengan aromaterapi dengan tujuan aromaterapi bisa mempercepat proses perubahan persepsi dengan mempengaruhi perubahan pada kognitif. Aroma bisa mempengaruhi persepsi seseorang, misalnya aroma bunga lavender atau bunga mawar yang menyegarkan bisa menimbulkan efek relaksasi sehingga bisa menurunkan kecemasan (Handayani 2018).

Hasil wawancara pada 10 orang pasien pre operasi mayor didapatkan 8 dari 10 responden mengalami kecemasan berat dan 2 pasien merasakan kecemasan sedang. Berdasarkan uraian latar belakang dan hasil studi pendahuluan, penulis tertarik untuk meneliti lebih lanjut mengenai apakah ada pengaruh spirizomacare terhadap tingkat kecemasan pada pasien pre operasi mayor di RSUD Cilegon.

\section{METODE PENELITIAN}

Dalam penelitian menggunakan pra ekperimental dengan rancangan penelitin one group pretest posttest. Populasi adalah pasien yang akan melakukan operasi mayor sebanyak 30 responden. Sampel diambil dengan teknik purposive sampling. Instrumen berupa kuesioner dan observasi. Teknik analisa data yang digunakan yaitu analisis univariat dan analisis bivariat dengan uji statistik Paired TFest.

\section{HASIL}

\section{Distribusi Frekuensi Responden Berdasarkan Usia}

Tabel : 1

Karakteristik responden berdasarkan usia $(\mathbf{N}=30)$

\begin{tabular}{ccc}
\hline Usia & Frekuensi & Presentase \\
\hline 19-26 tahun & 9 & $30 \%$ \\
\hline 27-34 tahun & 1 & $3,3 \%$ \\
\hline $35-42$ tahun & 9 & $30 \%$ \\
\hline$>42$ tahun & 11 & $36,7 \%$ \\
\hline Total & $\mathbf{3 0}$ & $\mathbf{1 0 0}$
\end{tabular}

Berdasar tabel 1 dapat dijelaskan dari 30 responden, mayoritas atau sebanyak 11 responden berusia $>42$ tahun dengan presentase $36,7 \%$. 


\section{Distribusi Frekuensi Responden Berdasarkan Jenis Kelamin \\ Tabel : 2}

Karakteristik responden berdasarkan jeniskelamin $(\mathbf{N}=\mathbf{3 0})$

\begin{tabular}{ccc}
\hline Jenis kelamin & Frekuensi & Presentase \\
\hline Laki-Laki & 15 & $50 \%$ \\
\hline Perempuan & 15 & $50 \%$ \\
\hline Total & $\mathbf{3 0}$ & $\mathbf{1 0 0}$ \\
\hline
\end{tabular}

Berdasar tabel 2 menunjukkan dari 30 responden, setengahnya atau sebanyak 15 responden berjenis kelamin lakilaki dengan presentase $50 \%$ dan setengahnya lagi berjenis kelamin perempuan sebanyak 15 responden dengan persentase $50 \%$.

3. Distribusi frekuensi tingkat Kecemasan sebelum dan sesudah diberikan spirizomacare

Tabel 3

Tingkat Kecemasan sebelum dan sesudah diberikanspirizomacare ( $\mathrm{N}=30$ )

\begin{tabular}{lrlll}
\hline Tingkat & \multicolumn{3}{c}{ Sebelum } & \multicolumn{2}{c}{ Sesudah } \\
\cline { 2 - 5 } Kecemasan & $\mathrm{N}$ & $\%$ & $\mathrm{~N}$ & $\%$ \\
\hline Tidak cemas & 0 & 0,0 & 0 & 0,0 \\
\hline Ringan & 0 & 0,0 & 12 & 40,0 \\
\hline Sedang & 9 & 30,0 & 18 & 60,0 \\
\hline Berat & 21 & 70,0 & 0 & 0,0 \\
\hline Total & $\mathbf{3 0}$ & $\mathbf{1 0 0 , 0}$ & $\mathbf{3 0}$ & $\mathbf{1 0 0 , 0}$ \\
\hline Berdasar tabel & 3 & diketahui bahwa \\
sebelum & Spirizomacare sebanyak 21 \\
(70\%) responden memiliki tingkat \\
kecemasan yang berat dan sebanyak 9 \\
(30\%) responden memiliki tingkat \\
kecemasan sedang. Berdasarkan data \\
diatas tedapat peningkatan penurunan \\
tingkat kecemasan yakni sebanyak 18 \\
(60\%) orang memiliki tingkat \\
kecemasan sedang, dan 12 (40\%) orang \\
memiliki kecemasan ringan.
\end{tabular}

\section{Hasil Uji Paired-Simpel T-Test}

Tabel 4

Uji Paired Simpel Test Tingkat Kecemasan

\begin{tabular}{lllllll}
\hline \multicolumn{7}{c}{ Kecemasan } \\
Kecemasan N & Mean & SD & Min & Max & $\begin{array}{c}\boldsymbol{P} \\
\text { Value }\end{array}$ \\
\hline Pre test & 30 & 3,70 & 466 & 0,986 & 1,213 & 0,000 \\
\hline Post test & 30 & 2,60 & 498 & & & \\
\hline \multicolumn{6}{c}{ Berdasar tabel 4} & hasil uji statistik \\
menunjukan & \multicolumn{2}{c}{ bahwa } & rata-rata \\
kecemasan sebelum & Spirizomacare \\
sebesar 3,70 & dan setelah & diberikan
\end{tabular}

spirizomacare didapatkan rata-rata kecemasan sebesar 2,60. Hasil uji statistik didapatkan nilai $\mathrm{p}$ sebesar $0,000<0,05$, maka dapat disimpulkan bahwa terdapat perbedaan anta kecemasan sebelum dan sesudah diberikan Spirizomacare pada Pasien Pre Operasi Mayor Di RSUD Cilegon.

\section{PEMBAHASAN}

\section{Karakteristik Responden Berdasarkan Usia}

Hasil penelitian menunjukkan dari 30responden mayoritas berusia $>42$ tahun $(36,7 \%)$. Hasil ini sejalan dengan penelitian Titin (2019), yang menemukan mayoritas responden berusia $>40$ tahun $(42,5 \%)$. Demikian juga dengan hasil penelitian Basri \& Lingga (2019), didapatkan hasil mayoritas pasien berusia $>50$ tahun $(53,1 \%)$. Hasil penelitian tersebut menjelaskan bahwa faktor yang memengaruhi kecemasan pasien sebelum operasi salah satunya faktor umur.

Hal tersebut sesuai teori Notoatmodjo, Q2014 yang menjelaskan bahwa umur berbanding lurus dengan kematangan seseorang dalam kognitif, semakin tinggi umur seseorang maka akan semakin matang dalam berfikir. Usia memiliki pengaruh besar pada kemampuan berpikir yang tergambar dalam sikapnya saat menghadapi masalah. Berdasar hasil penelitian dan teori yang ada, peneliti beransumsi bahwa usia berpengaruh terhadap tingkat kecemasan dimana kecemasan dipengaruhi dari tingkat kematangan berfikir seseorang.

2. Karakteristik Responden Berdasarkan Jenis Kelamin

Dari hasil penelitian didapatkan dari 30 responden, setengahnya berjenis kelamin laki-laki (50\%) dan setengahnya lagi berjenis kelamin perempuan (50\%). Penelitian ini sejalan dengan penelitian Saputri (2013), dengan hasil 50\% responden laki - laki dan 50\% dan responden perempuan. Demikian juga dengan penelitian yang dilakukan Paputangan (2019) dengan jumlah responden 32 orang terdiri dari 16 orang laki-laki dan 16 orang perempuan (masing-masing 50\%). Hasil penelitian 
tersebut menyatakan bahwa jenis kelamin berpengaruh untuk menilai tingkat kecemasan seseorang dimana antara lakilaki dan perempuan memiliki cara berbeda untuk mengatasi kecemasan (Paputungan et al. 2019).

\section{Tingkat Kecemasan Responden Sebelum dan Sesudah Diberikan Spirizomacare \\ Berdasar hasil penelitian diketahui} bahwa sebelum diberikan terapi Spirizomacare mayoritas responden mengalami tingkat kecemasan yang berat (70\%). Dan setelah diberikan terapi spirizomacare didapatkan hasil mayoritas responden mengalami tingkat kecemasan sedang $(60 \%)$.

Hasil tersebut sejalan dengan penelitian B a sri \& Lingga (2019) yang mendapatkan mayoritas pasien sebelum terapi mengalami kecemasan sedang $(75 \%)$ dan sesudah diberikan terapi mayoritas pasien berada pada kecemasan ringan (62,5\%). Kecemasan yang dirasakan pasien pre operasi sebagian besar disebabkan karena ketidaktahuan tentang prosedur operasi, sehingga timbul perasaan tidak tenang. Dalam pikiran mereka timbul bayangan-bayangan akibat persepsi mereka sendiri yang seringkali menambah rasa cemas (Lingga, 2019).

Penelitian ini sesuai dengaan penelitian Supriani (2017) yang didapatkan hasil tingkat kecemasan sebelum dilakukan terapi yaitu tingkat kecemasan berat $(70 \%)$ dan kecemasan sedang $(30 \%)$. Sesudah diberikan terapi didapatkan sebanyak $70 \%$ mengalami penurunan kecemasan menjadi cemas ringan.

Peneliti beransumsi terapi komplementer mempengaruhi tingkat kecemasan seseorang baik sebelum maupun sesudah diberikan terapi serta respon cemas seseorang pun memiliki perbedaan disetiap individu (Supriani et al. 2017).

4. Pengaruh Spirizomacare Terhadap Tingkat Kecemasan Pasien Pre Operasi Mayor

Hasil analisis uji statistik didapatkan nilai $\mathrm{p}$ sebesar $0,000<0,05$, sehingga bisa diambil kesimpulan ada perbedaan yang signifikan pada tingkat kecemasan setelah diberikan terapi Spirizomacare pada Pasien Pre Operasi Mayor Di RSUD Cilegon.

Hasil tersebut sejalan dengan penelitian Rahmayanti (2018) yang menggunakan uji statistik Wilcoxon Signed Ranks Test mendapatkan P-value sebesar $0,001>0,05$, hal tersebut menunjukkan bahwa terapi dukungan spritual berpengaruh dalam penurunan kecemasan pasien pre operasi.

Hal tersebut juga didukung hasil penelitian Supriani (2017) yang menemukan adanya pengaruh dari intervensi bimbingan relaksasi spiritual yang diberikan sebelum tindakan operasi terhadap tingkat kecemasan responden, hal tersebut dibuktikan dengan hasil uji Wilcoxon didapatkan nilai $\mathrm{p}=0,000(\leq 0,05)$.

Berdasarkan hasil penelitian, peneliti menyimpulkan jika terapi spiritual dengan relaksasi dan aromaterapi atau spirizomacare berpengaruh terhadap penurunan kecemasan dimana pada terapi spiritual perlu perilaku care dari perawat serta meningkatkan stimulus untuk menurunkan tingkat kecemasan.

\section{KESIMPULAN}

Sebelum diberikan terapi Spirizomacare tingkat kecemasan berat sebanyak $70 \%$, tingkat kecemasan sedang sebanyak $30 \%$. Setelah diberikan terapi spirizomacare didapatkan tingkat kecemasan sedang sebanyak $60 \%$ dan tingkat kecemasan ringan sebanyak $40 \%$. Ada pengaruh spririzomacare terhadap tingkat kecemasan pada klien sebelum melakukan pre operasi mayor di RSUD Cilegon (P value 0,000 ).

Diharapkan responden dapat untuk mengidentifikasi kecemasan dan cara mengontrol kecemasan dengan baik dan dapat mengontrol kecemasan secara mandiri. Rumah sakit dapat memberikan pendidikan kesehatan kepada seluruh pasien mengenai mengontrol kecemasan. Sehingga diharapkan tidak terjadi kecemasan yang berat pada pasien yang akan melakukan operasi.

\section{DAFTAR PUSTAKA}

Ahsan Adam Malik (2018). Faktor-Faktor Yang Mempengaruhi Kecemasan Pre Operasi Pada Pasien Sectio Caesarea Di Ruang Instalasi Bedah Sentral 
RSUD Kanjuruhan Kepanjen Kabupaten Malang. Ejournal UMM, 8:1-12.

Fadli, Irmayanti Toalib, And Kassaming. (2017). Kecemasan Pada Pasien Pre Operasi Mayor. Jurnal Ilmiah Kesehatan Diagnosis. Volume 13(6): $1-5$.

Handayani, S. (2019). Pengaruh Spiriziomacare Terhadap Kecemasan dan Tanda Vital Klien Sebelum Kateterisasi Jantung. Surabaya: http://repository.unair.ac.id/id/eprint/779 $\underline{57 .}$

Basri, \& Lingga, D. L. (2019). Pengaruh Terapi Musik Klasik Terhadap Kecemasan Pasien Pre Operasi di Instalasi Bedah Pusat RSUP H. Adam Malik Medan Tahun 2018. Jurnal Keperawatan Priority, Vol. 2, No. 2, 41-50.

Notoatmodjo. (2014). Promosi Kesehatan Dan Perilaku Kesehatan.. Jakarta: PT Rineka Cipta.

Paputungan, et al. (2019). Perbedaan Tingkat Kecemasan Berdasarkan Jenis Kelamin Pada Tindakan Penumpatan Gigi. E-Clinic 7(2): 71-76.

Rahmayati, et al. (2018). Pengaruh Dukungan Spritual Terhadap Tingkat Kecemasan Pada Pasien Pre-Operasi. Jurnal Kesehatan 9(1): 138.

Rizki, et al. (2019). Health Education Using The Leaflet Media Reduce Anxiety Levels In Pre Operation Patients. Jendela Nursing Journal 3(1): 49.

Rokawie, et al. (2017). Relaksasi Nafas Dalam Menurunkan Kecemasan Pasien Pre Operasi Bedah Abdomen. Jurnal Kesehatan 8 (2): 257.

Saputri, et al. (2013). Hubungan Jenis Kelamin Dengan Tingkat Kecemasan Pada Pasien Pre Operasi Di Ruang Bedah RS. Baladhika Husada Jember. Journal Of Chemical Information And Modeling 53(9): 1689-99.
Supriani, et al. (2017). Pengaruh Bimbingan Relaksasi Spiritual Terhadap Kecemasan Pada Pasien Pre Operasi di Ruang Sunan Drajat RSI Sakinah Kabupaten Mojokerto. Nurse And Health: Jurnal Keperawatan 6(2):3039.

Titin, Marlina Theresia. (2019). Tingkat Kecemasan Pasien Sebelum Dan Sesudah Pembedahan Di Rumah Sakit Swasta Yogyakarta. Media Ilmu Kesehatan 6(3): 225-31. 